CLINICAL STUDY

\title{
Severity of cardiovascular disease in postmenopausal women: associations with common estrogen receptor $\alpha$ polymorphic variants
}

\author{
M Alevizaki ${ }^{1,2}$, K Saltiki ${ }^{1,2}$, A Cimponeriu ${ }^{2}$, I Kanakakis ${ }^{2}$, N Xita ${ }^{3}$, C C Alevizaki ${ }^{1}$, I Georgiou ${ }^{3}$ and H-L Sarika ${ }^{2}$ \\ ${ }^{1}$ Endocrine Unit, Evgenidion Hospital and ${ }^{2}$ Department of Medical Therapeutics, Alexandra Hospital, Athens University School of Medicine, 11528 \\ Athens, Greece and ${ }^{3}$ Medical Genetics Unit, Department of Obstetrics and Gynaecology, University of Ioannina, Medical School, 45110 Ioannina, Greece \\ (Correspondence should be addressed to M Alevizaki who is now at Athens University School of Medicine, 80, Vassilisis Sofias Ave., 11528 Athens, Greece; \\ Email:mani@otenet.gr)
}

\begin{abstract}
Objective: Impaired estrogen action is a risk factor for coronary artery disease (CAD). Associations of CAD with estrogen receptor $\alpha(\mathrm{ER} \alpha)$ polymorphisms, which may influence sensitivity to estrogen, have been reported for men; the data concerning women are not conclusive. We investigated the association of common $\mathrm{ER} \alpha$ polymorphisms with the severity of $\mathrm{CAD}$ and with metabolic and reproductive factors in postmenopausal women undergoing coronary angiography.

Methods: ER $\alpha$ polymorphisms at positions c.454-397 T > C (PvuII) and c.454-351 A> G (XbaI) were studied in 157 women (age 45-88 years). The severity of CAD was assessed by the number of arteries with $>50 \%$ stenosis in the angiography.

Results: There was a significant association between the TT, TC, and CC genotypes (PvuII) and the severity of CAD $(P=0.008)$; similar results were obtained for the XbaI polymorphism $(P=0.021)$. These associations were independent of other risk factors for CAD. Women homozygous for the $C$ allele had significantly higher triglyceride and insulin levels; they belonged more frequently to the group with a low number of births ( $\mathrm{n} \leq 1 ; P=0.014$, Fisher's exact).

Conclusions: Common ER $\alpha$ polymorphisms may influence the severity of CAD in women undergoing coronary angiography, reflecting lifetime exposure to estrogen. Similar associations have been reported for men with CAD. These polymorphisms should probably be taken into account when associations with estrogenic actions are examined.
\end{abstract}

European Journal of Endocrinology 156 489-496

\section{Introduction}

Coronary artery disease $(\mathrm{CAD})$ is a multifactorial disease with a definite genetic element, however the genetic risk factors involved remain obscure (1).

Sex hormones are important for the development of CAD as suggested by the sex difference in the occurrence of $\mathrm{CAD}$ between premenopausal women and age matched men. This difference almost disappears in postmenopausal women (2-4). Several lines of evidence suggest that endogenous estrogens have a protective effect against the development of CAD for both men and women (5-7).

The beneficial action of endogenous estrogens on the cardiovascular system is effected both directly and indirectly. Directly, through both genomic and non-genomic mechanisms, estrogens have a vasodilatating, anti-inflammatory and antiproliferative action, while indirectly they favorably influence the lipidemic profile and affect coagulation and fibrinolysis factors $(6,8-10)$.
The genomic actions of estrogens are mediated through the two known nuclear estrogen receptors (ER $\alpha$ and ER $\beta ;(11,12)$ ). ER $\alpha$ is expressed in endothelial cells (13) and vascular smooth muscle cells (14-17), where it affects the transcription of several genes involved in vascular function $(6,8,9)$. Genetic polymorphisms of the ERs may affect the transcriptional function of the ERs and thus the tissue response to estrogen. Such polymorphisms are common sequence variants (mostly single nucleotide polymorphisms (SNPs)), which are conventionally present in $>1 \%$ in the population. On the other hand, a mutation is a rare change in genetic material, which usually causes a disease phenotype. An extreme example of dysfunction of the receptor has been reported in a young man who carried an inactivating mutation in the $E R \alpha$ gene, causing severe estrogen resistance; this individual manifested premature atherosclerosis despite high circulating levels of estrogens (18). Since this report, several studies have investigated common ER $\alpha$ SNPs, specifically the PvuII and XbaI examples, in connection 
with clinical, angiographic and biochemical parameters predisposing for cardiovascular disease, both in men (19-26) and women (19-24). Most of these studies have focused on men and the results concerning women are inconclusive. More rarely other polymorphisms of $E R \alpha$ gene like the (TA)n polymorphism have been examined (22, 27-29). In the present study, we investigated the possible influence of the two common polymorphisms of $\mathrm{ER} \alpha$, c.454-397 T>C (PvuII) and c.454-351 A>G $(\mathrm{XbaI})$, in the manifestation and severity of CAD, focusing only on postmenopausal women and specifically on a highly selected group of women who are undergoing coronary angiography for suspected CAD.

\section{Patients and methods}

One hundred and seventy eight consecutive women who were referred for coronary angiography during a period of 2 years (from September 2003 to February 2006) were examined for evaluation of CAD. Of these women, 173 underwent coronary angiography for diagnostic reasons and 5 were evaluated a few days after an acute coronary attack. Clinical suspicion for CAD was based on the following criteria: angina, atypical chest pain, previous myocardial infarction, positive stress test, atrial fibrillation, cardiac arrhythmias, dyspnea during exercise, valve disease and strong family history for CAD. Sixteen women were excluded from the analysis for the following reasons: one had undergone heart transplantation, one had acromegaly, three were on long-term therapy with corticosteroids, four were not of Greek ethnic origin, seven were premenopausal and a further five women refused to participate in the study. Thus, 157 women were finally genotyped. This group of women were of Greek ethnic origin and all the patients included in the study were informed of the aim of the study and gave their consent. The protocol was approved by the hospital's Ethics Committee.

The recorded clinical data included: current age, age at onset of CAD and clinical parameters of cardiovascular disease: history of angina and myocardial infarctions, presence of risk factors such as hypertension, diabetes mellitus, dyslipidemia, smoking $(>10$ cigarettes per day at time of assessment or during the last 2 years prior to $\mathrm{CAD}$ ), drug therapy, alcohol use, and family history for premature $\mathrm{CAD}$, diabetes mellitus, and dyslipidemia. A detailed gynecological and reproductive history was also recorded concerning age at menarche and menopause, number of menstrual cycles per year, past and current use of HRT and/or contraceptive medication, number of pregnancies, live births and abortions. At clinical examination height and weight were measured with women wearing indoor clothes without shoes; body mass index (BMI) was used to estimate obesity; waist perimeter and waist to hip ratio was used to evaluate fat distribution. Blood pressure was measured with a mercury sphygmomanometer while women were in the supine position.
The extent of CAD was assessed by the number of arteries (0-3) with more than 50\% stenosis of their luminar diameter in the angiography as confirmed by two independent cardiologists. The age range of the women who participated in the study was $45-88$ years. Thirty three women had one, 34 had two and 20 had three vessel disease, while the remaining 70 subjects turned out to have zero vessels with important stenosis and thus served as the control group. The characteristics of the women participating in the study are shown in Table 1.

\section{Hormonal and biochemical investigation}

Fasting blood samples were obtained by venipuncture between 0800 and $0900 \mathrm{~h}$. Biochemical parameters such as glucose, total cholesterol, high density cholesterol (HDL), low density cholesterol (LDL), triglycerides and uric acid, were measured immediately. Insulin, estradiol, total testosterone and sex hormone binding globulin were measured in consecutive assays in sera that had been stored at $-20^{\circ} \mathrm{C}$. Estradiol was measured using the method Spectria E2 sensitive (Orion Diagnostica, Espoo, Finland), testosterone by RIA (Biosource Europa SA, Nivelles, Belgium), and serum insulin by IRMA (Biosource Europa SA). Basal insulin resistance index (HOMA) was calculated using the formula: insulin resistance $=\mathrm{FI} \times G / 22.5$, where $\mathrm{FI}$ is the fasting insulin $(\mu \mathrm{U} / \mathrm{ml})$ and $G$ is the fasting glucose $(\mathrm{mmol} / \mathrm{l})$.

\section{Molecular analysis}

DNA was extracted from peripheral lymphocytes. Polymorphisms of ER $\alpha$ at positions c.454-397 $\mathrm{T}>\mathrm{C}$ (PvuII) and c.454-351 A>G (XbaI) were genotyped. PCR was performed in a DNA thermocycler using one unit of TaqDNA polymerase per reaction. The primers used were:

5'CTGCCACCCTATCTGTATCTTTTCCTATTCTCC-3' (forward)

5'-TCTTTCTCTGCCACCCTGGCGTCGATTATCTGA-3' (reverse) (30). The database source for the primers was: www.ncbi.nlm.nih.gov/Genbank; identification number $\mathrm{xbaI}=\mathrm{rs} 9340799$ and $\mathrm{pvuII}=\mathrm{rs} 2234693$.

Table 1 Characteristics of postmenopausal women evaluated for possible coronary artery disease (CAD; $n=157)$.

\begin{tabular}{lccc}
\hline & $\%$ & Mean $( \pm \mathrm{S} . \mathrm{E})$ & Range \\
\hline Age (years) & & $65.0 \pm 0.95$ & $65.0 \pm 0.95$ \\
Number of deliveries $(n=124)$ & & $2.22 \pm 0.1$ & $0-9$ \\
Age at menopause (years) & & $48.4 \pm 0.5$ & $28-61$ \\
Time since menopause (years) & & $18.9 \pm 0.9$ & $0.5-43$ \\
Hypertension & 66.5 & & \\
Hypercholesterolemia & 76.4 & & \\
Hypertriglyceridemia & 37.4 & & \\
Diabetes mellitus & 25.3 & & \\
Smoking & 25.4 & & \\
BMl $\left(\mathrm{kg} / \mathrm{m}^{2}\right)$ & & $28.3 \pm 0.3$ & $16.2-44$ \\
W/H ratio & & $0.9 \pm 0.006$ & $0.71-1.2$ \\
\hline
\end{tabular}


The reaction product contained a fragment of intron 1 and exon 2 of $\mathrm{ER} \alpha$ where the restriction enzyme recognition sites are located. Subsequently, the product was digested with two units of the enzyme PvuII (GIBCO BRL) for $2 \mathrm{~h}$ and with two units of the enzyme XbaI for $24 \mathrm{~h}$. Finally, the digested PCR product was subjected to electrophoresis in $2 \%$ agarose gel with the appropriate molecular size markers and the results were photographed under u.v. light. The genotype PvuII was characterized as $\mathrm{CC}, \mathrm{CT}$ and $\mathrm{TT}$, where the T allele characterizes the existence of a PvuII site, and C the absence of this site. Similarly, the genotype $X b a \mathrm{I}$ was characterized as AA, AG and GG, where the A allele characterizes the existence of a $\mathrm{XbaI}$ site, and the $\mathrm{G}$ allele the absence of this site. Accuracy of the restriction fragment length polymorphism was verified by performing duplicate reactions in 5\% of the samples. In all cases identical results were obtained. Haplotype analysis taking into account both polymorphic sites, which are tightly linked, was also performed. The most frequent haplotypes in our population were TA (group 1) and CG (group 2), followed by CA and TG.

\section{Statistical analysis}

For contingency tables the $\chi^{2}$ statistic with Yates correction and the $\chi^{2}$ test for linear association (Mantel-Haenszel $\chi^{2}$ ) were used. Correlations between continuous variables were calculated by linear regression model (Pearson correlation). Multivariate analysis (step multiple regression) was performed including as possible confounders all the variables for which there was some correlation which was statistically significant, or tending to be significant, in the univariate analysis. Where the distribution was normal, $t$-test was used for comparing the means, otherwise the Mann-Whitney (M-W) rank test was used for comparing central tendency.

\section{Results}

The distribution of PvuII ER $\alpha$ variants was as follows: $\mathrm{TT}=36.3 \%, \mathrm{TC}=48.4 \%$ and $\mathrm{CC}=15.3 \%$. On the basis of these findings the incidence of the T allele was $60.5 \%$ and the $\mathrm{C}$ allele $39.5 \%$ (Table 2). The distribution of XbaI polymorphism of $\mathrm{ER} \alpha$ was: $\mathrm{AA}=33.1 \%, \mathrm{AG}=$ $52.9 \%$ and $\mathrm{GG}=14 \%$; the occurrence of the A allele was $59.5 \%$ and of the $\mathrm{G}$ allele $40.5 \%$ (Table 2). This distribution did not differ from that expected according to the Hardy-Weinberg equilibrium. There was a significant correlation between PvuII polymorphism of $\mathrm{ER} \alpha$ and CAD severity as expressed by the number of arteries with a significant stenosis in the coronary angiography (Table 3, Fig. 1), the Mantel-Haenszel test for linear association giving a $P$ value of 0.008 . This association remained statistically significant irrespective of whether the analysis was considered towards
Table 2 Distribution of genotypes c.454-397 T>C (Pvull) and c.454-351 A $>\mathrm{G}($ Xbal) of estrogen receptor $(E R \alpha)$ in postmenopausal women undergoing coronary angiography $\mathrm{B}$.

\begin{tabular}{lcc}
\hline & Frequency & $\%$ \\
\hline Pvull genotype & & \\
Homozygous TT & $57 / 157$ & 36.3 \\
Heterozygous TC & $76 / 157$ & 48.4 \\
Homozygous CC & $24 / 157$ & 15.3 \\
Xbal genotype & & \\
Homozygous AA & $52 / 157$ & 33.1 \\
Heterozygous AG & $83 / 157$ & 52.9 \\
Homozygous GG & $22 / 157$ & 14.0 \\
\hline
\end{tabular}

increasing frequencies of the $\mathrm{C}$ allele, i.e. TT, TC and CC, or the presence or not of the $\mathrm{C}$ allele, or when comparing homozygotes vs heterozygotes for this allele.

Similar results were obtained when considering the XbaI polymorphism: the presence of allele G showed a positive association with the presence of stenosis in more than one coronary arteries $(P=0.021$, MantelHaenszel test for linear association; Table 3, Fig. 2). Multivariate (step) analysis showed that these associations were independent of chronological age, age at menopause or time since menopause (Table 4). In a different model, the associations of the severity of CAD with hypertension, hypercholesterolemia, insulin levels, and the PvuII ER $\alpha$ polymorphism were considered. Multivariate (step) analysis showed that the association of PvuII ER $\alpha$ remained significant (Table 4). Similar results were obtained when HOMA basal insulin resistance was used instead of insulin. No associations

Table 3 Association of genotypes c.454-397 T>C (Pvull) and c. 454-351 A $>\mathrm{G}$ (Xbal) of the $E R \alpha(A)$ and respective haplotypes (group 2 CG) (B) with the severity of cardiovascular disease (0-3 vessels with more than $50 \%$ stenosis) in postmenopausal women ( $P=0.008$ and $P=0.021$ respectively for genotypes, $P=0.02$ for haplotype analysis, Mantel-Haenszel test for linear association).

\begin{tabular}{|c|c|c|c|c|}
\hline & 0 Vessels & 1 Vessel & 2 Vessels & 3 Vessels \\
\hline \multicolumn{5}{|c|}{ A. Genotype Pvull } \\
\hline TT & $\begin{array}{l}32 \\
45.7 \%\end{array}$ & $\begin{array}{l}11 \\
33.3 \%\end{array}$ & $\begin{array}{l}10 \\
29.4 \%\end{array}$ & $\begin{array}{l}4 \\
20 \%\end{array}$ \\
\hline CT & $\begin{array}{l}31 \\
44.3 \%\end{array}$ & $\begin{array}{l}17 \\
51.5 \%\end{array}$ & $\begin{array}{l}17 \\
50 \%\end{array}$ & $\begin{array}{l}11 \\
55 \%\end{array}$ \\
\hline $\mathrm{CC}$ & $\begin{array}{l}7 \\
10 \%\end{array}$ & $\begin{array}{l}5 \\
15.2 \%\end{array}$ & $\begin{array}{l}7 \\
20.6 \%\end{array}$ & $\begin{array}{l}5 \\
25 \%\end{array}$ \\
\hline \multicolumn{5}{|l|}{ Xbal } \\
\hline AA & $\begin{array}{l}27 \\
38.6 \%\end{array}$ & $\begin{array}{l}11 \\
33.3 \%\end{array}$ & $\begin{array}{l}10 \\
29.4 \%\end{array}$ & $\begin{array}{l}4 \\
20 \%\end{array}$ \\
\hline GA & $\begin{array}{l}37 \\
52.9 \%\end{array}$ & $\begin{array}{l}18 \\
54.6 \%\end{array}$ & $\begin{array}{l}17 \\
50 \%\end{array}$ & $\begin{array}{l}11 \\
55 \%\end{array}$ \\
\hline GG & $\begin{array}{l}6 \\
8.5 \%\end{array}$ & $\begin{array}{l}4 \\
12.1 \%\end{array}$ & $\begin{array}{l}7 \\
20.6 \%\end{array}$ & $\begin{array}{l}5 \\
25 \%\end{array}$ \\
\hline \multicolumn{5}{|c|}{ B. Haplotype (group 2-CG) } \\
\hline 0 Copy & $\begin{array}{l}35 \\
50.0 \%\end{array}$ & $\begin{array}{l}12 \\
36.4 \%\end{array}$ & $\begin{array}{l}11 \\
32.4 \%\end{array}$ & $\begin{array}{l}6 \\
30.0 \%\end{array}$ \\
\hline 1 Copy & $\begin{array}{l}29 \\
41.4 \%\end{array}$ & $\begin{array}{l}18 \\
54.5 \%\end{array}$ & $\begin{array}{l}17 \\
50.0 \%\end{array}$ & $\begin{array}{l}10 \\
50.0 \%\end{array}$ \\
\hline 2 Copies & $\begin{array}{l}6 \\
8.6 \%\end{array}$ & $\begin{array}{l}3 \\
9.1 \%\end{array}$ & $\begin{array}{l}6 \\
17.6 \%\end{array}$ & $\begin{array}{l}4 \\
20.0 \%\end{array}$ \\
\hline
\end{tabular}




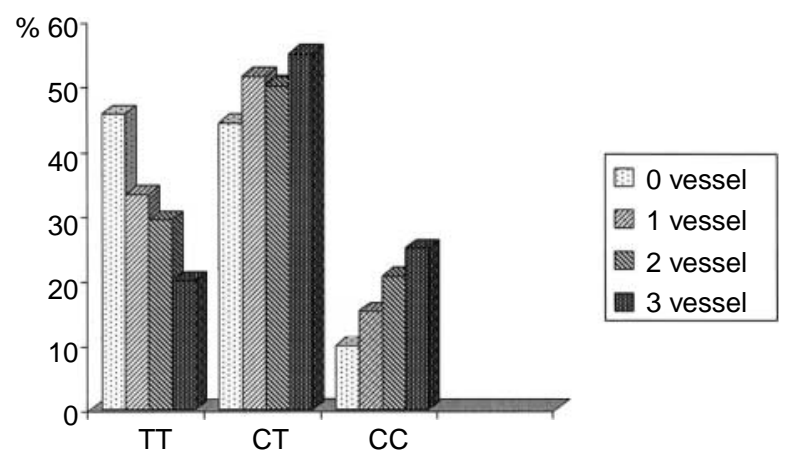

Figure 1 Distribution (\%) of the three genotypes (Pvull) of estrogen receptor $(E R \alpha)$ according to the number of coronary arteries $(0-3)$ with more than $50 \%$ stenosis in postmenopausal women $(P=0.008)$.

were found in the occurrence of angina or myocardial infarction and the age at onset of cardiovascular symptoms according to genotype.

Haplotype analysis taking into account these two polymorphic sites showed that the most frequent haplotypes in our population were TA $(57 \%)$ - group1 and CG (34\%) - group 2; haplotype CA was found in $4.5 \%$ and $\mathrm{TG}$ in $4.5 \%$. Women carrying two copies of the CG haplotype belonged more frequently to the subgroup with more severe $\mathrm{CAD}\left(P=0.02, \chi^{2}\right.$ test for linear association, Table 3); the level of significance was roughly the same as with genotype analysis (Table 3).

The following parameters were significantly higher in the group of women who were homozygous for the Pvu2 $\mathrm{C}$ allele when compared with the group of $\mathrm{T}$ carriers. Insulin levels were significantly increased, $19.1 \pm 10.9$ vs $14.5 \pm 8.9(P=0.044, \mathrm{M}-\mathrm{W}$ test $)$ and so was waist to hip ratio: $0.93 \pm 0.01$ vs $0.9 \pm 0.07 \mu \mathrm{U} / \mathrm{ml}(P=0.028$ $\mathrm{M}-\mathrm{W}$ test). No significant differences were found in the total cholesterol, LDL, HDL cholesterol or triglyceride levels in either the frequency of use of lipid lowering drugs or the HOMA-IR index. The same was true for

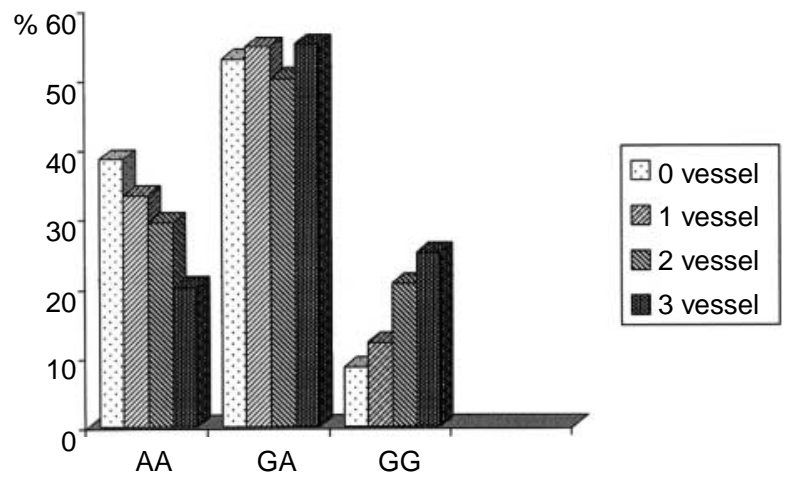

Figure 2 Distribution (\%) of the three genotypes (Xbal) of estrogen receptor $(\mathrm{ER} \alpha)$ according to the number of coronary arteries $(0-3)$ with more than $50 \%$ stenosis in postmenopausal women $(P<0.021)$. age, BMI and the presence of diabetes mellitus; arterial blood pressure was marginally higher in CC homozygotes $(137.2+3.1$ vs $130.2+1.6, P=0.055$, $\mathrm{M}-\mathrm{W}$ test). Mean estrogen or testosterone levels did not differ between the two genotype groups of postmenopausal women (mean testosterone $440 \pm 90$ vs $402 \pm$ $38 \mathrm{pmol} / \mathrm{l}$, mean estradiol $2.05 \pm 0.26$, vs $2.2 \pm$ $0.15 \mathrm{pmol} / \mathrm{l}, \mathrm{ns})$.

The effect of the ER $\alpha$ PVUII polymorphism on the age of menarche and the age at menopause as well as menstrual cycle frequency and number of live births was next considered; no significant association of the polymorphism was found with age at menarche, age at menopause, or the frequency of menstrual cycles. A significant association was found in the number of births (information available for only 124 of the women) between women homozygous for the $\mathrm{C}$ allele and carriers of the wild type allele (either homozygous or heterozygous); of women homozygous for the $\mathrm{C}$ allele, $38.9 \%$ belonged to the group with a low number of births $(\leq 1)$, while of women carrying the $\mathrm{T}$ allele only $13 \%$ belonged to the group with births $\leq 1 \quad(P=0.014$, Fisher's exact, two-tailed).

Several classical risk factors for CAD were significantly associated with the severity of CAD, such as current age, hyperlipidemia, positive family history for early CAD, waist perimeter and the presence of diabetes mellitus (not shown).

\section{Discussion}

In this study, we investigated the possible effect of ER $\alpha$ polymorphisms on the severity of CAD in women referred for coronary angiography. We found evidence that ERs, which influence the estrogen action at the tissue level, may play an important role in the development of more severe CAD in this highly selected group of postmenopausal women. In our investigation, we did not perform any study to assess sensitivity to estrogen; however, we found that ER variants, which may be associated with modified estrogenic action $(19,22,23)$, are independently associated with more severe CAD. This further supports the important role of estrogens in cardiovascular health and agrees with the significant effect of the duration of total lifetime endogenous estrogen exposure that we have recently reported (31).

These findings point to the same direction with the majority of reports about the effects of estrogen in men $(19,25,32)$. The population studies showed that some ER variants are consistently associated with clinical parameters, which predispose to atherosclerosis and cardiovascular incidents. Thus, a recent large epidemiological study in a subpopulation of the Framingham study (19) showed that men carrying the PvuII variant (C allele) had three times higher risk for progressive cardiovascular disease and myocardial infarction. Because of the small number of events among the 
Table 4 Results of multivariate analysis by stepwise linear regression between severity of CAD (0-3 vessels with $>50 \%$ stenosis) as dependent variable and $\mathrm{ER} \alpha$ polymorphisms and possible confounders as predictors in postmenopausal women undergoing coronary angiography.

\begin{tabular}{|c|c|c|c|c|c|}
\hline Dependent variable & Predictor & $\boldsymbol{\beta}$ & $t$ & Significance $P$ & Overall $\boldsymbol{R}^{2}(\%)$ \\
\hline \multicolumn{6}{|l|}{ Model $1^{a}$} \\
\hline \multirow[t]{4}{*}{ Severity of CAD } & Age at menopause & & 0.621 & 0.536 & 0.336 \\
\hline & Time since menopause & & 0.621 & 0.536 & $P<0.001$ \\
\hline & Age & 0.242 & 2.652 & 0.008 & \\
\hline & Xbal ER $\alpha$ polymorphism & 0.233 & 2.619 & 0.01 & \\
\hline \multicolumn{6}{|l|}{ Model 2} \\
\hline \multirow[t]{4}{*}{ Severity of CAD } & Hypertension & 0.193 & 2.19 & 0.031 & 0.347 \\
\hline & Hypercholesterolemia & 0.312 & 3.73 & 0.001 & $P<0.001$ \\
\hline & Pvull ER $\alpha$ polymorphism & 0.199 & 2.26 & 0.026 & \\
\hline & Insulin levels & 0.516 & 2.62 & 0.01 & \\
\hline
\end{tabular}

aThe standardized regression coefficients $(\beta)$ together with their statistical significance tests and multiple correlation coefficient are shown in two models which correspond to two different sets of possible confounders, identified by preliminary univariate analysis.

women who were investigated in that study, no report of the corresponding risk in women was calculated. Furthermore, recently it was found that the $\mathrm{CC}$ genotype was an independent risk factor for myocardial infarctions in a large sample originating from five compiled populations (25). The importance of this polymorphism was also confirmed in a study performed in men who had a higher risk of stroke when they were homozygous for the C allele (26). Two further studies from Finland are in accordance with this finding. The first one of these was carried out in healthy men and found a positive association between the presence of this variant and premature coronary artery dysfunction (32), while the other showed that in postmortem investigations a much higher incidence of atherosclerosis was found in PvuII carriers (33).

The Rotterdam study (20) is the only study to have so far reported results which do not agree with ours. In the study in question, a random sample of the population was examined for the incidence of $\mathrm{CAD}$ for a 7-year period, and the findings suggested that the combination of the haplotype $\mathrm{T}$ and $\mathrm{A}$ in the PvuII and XbaI polymorphic sites respectively is an important risk factor for coronary heart disease events exclusively in women. We cannot offer an explanation for this difference. It should be noted, however, that the results of our study cannot be extrapolated to the general population, as it was performed in a highly selected group of subjects who, as a group, had a significant number of other risk factors for cardiovascular disease. Finally, there are several studies which found no statistically significant correlations between these ER $\alpha$ polymorphisms and coronary heart disease events (21) or the presence and the severity of coronary atherosclerosis $(34,35)$ in either sex.

Our results indirectly agree with the findings of several - although not all - other studies, which suggest that the effect of polymorphisms of ERs may modify the exposure of various tissues to estrogens thus resulting in different clinical phenotypes in diseases, such as breast cancer (36-39), endometrial carcinoma (40), and osteoporosis (41-43). It is also possible that these variants may influence clinical parameters such as age of menarche and menopause $(44,45)$; in this way these polymorphisms may influence the length of exposure to the protective effect of estrogens during reproductive years. Other clinical parameters associated with these ER variants are the presence of endometriosis (46) and higher systolic arterial blood pressure (47). In fact in our study too, women carrying the PvuII T>C polymorphism had a tendency for association with higher systolic arterial blood pressure, which did not reach statistical significance.

It is also possible that ER activity may participate in the observed differences in features of the metabolic syndrome. We found that insulin levels were higher and central obesity was more common in allele C homozygotes. Other studies have shown positive associations between LDL cholesterol levels and ER $\alpha$ polymorphisms in healthy children homozygous for the XbaI G allele (48) and in female smokers homozygous for the PvuII T allele (49), whereas Matsubara et al. have not found any association between lipid levels and ER genotypes (35). Finally, ER $\alpha$ polymorphisms have been very recently associated with insulin sensitivity and the metabolic syndrome only in women of Asian origin participating in the Study of Women's Health Across the Nation (50).

One possibly interesting observation is the association with the number of deliveries in this population, showing a higher representation of homozygous PvuII $\mathrm{C}$ allele carriers among the women with a low birth rate. This finding needs to be confirmed in a larger population sample of normal women, but possibly agrees with the later start of ovulatory cycles and earlier menopause that have been reported $(44,45)$ and the importance of this receptor for reproductive function. Interestingly, our previous observation concerning the success rate of in vitro fertilization points to the same direction (51). In their population study, Weel et al. (45) did not find any differences although no detailed information was available. 
There are several studies in the literature supporting the functional importance of the ER $\alpha$ polymorphisms, studied in the present study. It has been speculated that this intronic site, which is situated at a distance between 397 and 351 nucleotides from exon 2, might result in alternative splicing, thus modifying the gene's function as has been reported for other genes $(52,53)$. It is also possible that this site might be the locus of attachment of a transcription factor, B-myb, which is nullified when nucleotide $\mathrm{T}$ is present, thus affecting the speed of transcription of the receptor gene $(54,55)$. Finally, it is possible that this polymorphic site is linked to some other locus, which has a role in cardiovascular disease. It has been reported that the PvuII intronic polymorphism is linked to the polymorphic TATA repeat site in the ER $\alpha$ promoter region (56).

One limitation of our study is the relatively small number of subjects studied resulting in comparatively small genotype groups and thus our results may not be generalized. However, these women belonged to a highly selected group with possibly multiple predisposing factors and the observed effect was independent of other factors. Thus, although these results cannot be extrapolated to the general population, they show that within this group of women the genotype of sex hormone receptor may be of importance for the severity of CAD as it has been previously shown for men $(19,25$, 57 ), obviously reflecting the long-term effects of sensitivity to hormonal action.

In conclusion, common polymorphisms of the $E R \alpha$ gene, which probably modify estrogen action at the tissue level, may affect the severity of CAD in a population of highly selected women who were referred for coronary angiography, since they probably reflect the degree of past tissue exposure to estrogens. This association is independent of other classical risk factors for CAD. If these results are confirmed in a larger population sample these polymorphisms should probably be taken into account when associations with estrogenic action are examined.

\section{References}

1 Yamada $\mathrm{Y}$, Izawa $\mathrm{H}$, Ichihara $\mathrm{S}$, Takatsu $\mathrm{F}$, Ishihara $\mathrm{H}$, Hirayama H, Sone T, Tanaka M \& Yokota M. Prediction of the risk of myocardial infarction from polymorphisms in candidate genes. New England Journal of Medicine 2002347 1916-1923.

2 Barrett-Connor E. Clinical review 162: cardiovascular endocrinology 3: an epidemiologist looks at hormones and heart disease in women. Journal of Clinical Endocrinology and Metabolism 200388 4031-4042.

3 Isles CG, Hole DJ, Hawthorne VM \& Lever AF. Relation between coronary risk and coronary mortality in women of the Renfrew and Paisley survey: comparison with men. Lancet 1992339 702-706.

4 Gordon T, Kannel WB, Hjortland MC \& McNamara PM. Menopause and coronary heart disease. The Framingham study. Annals of Internal Medicine $1978 \mathbf{8 9} 157-161$.
5 Barrett-Connor E \& Bush TL. Estrogen and coronary heart disease in women. JAMA 1991265 1861-1867.

6 Mendelsohn ME \& Karas RH. The protective effects of estrogen on the cardiovascular system. New England Journal of Medicine 1999 340 1801-1811.

7 Sudhir K \& Komesaroff PA. Cardiovascular actions of estrogens in men. Journal of Clinical Endocrinology and Metabolism $1999 \mathbf{8 4}$ 3411-3415.

8 Turgeon JL, Carr MC, Maki PM, Mendelsohn ME \& Wise PM. Complex actions of sex steroids in adipose tissue, the cardiovascular system, and brain: insights from basic science and clinical studies. Endocrine Reviews 200627 575-605.

9 Gruber CJ, Tschugguel W, Schneeberger C \& Huber JC. Production and actions of estrogens. New England Journal of Medicine 2002 346 340-352.

10 Mudali S, Dobs AS, Ding J, Cauley JA, Szklo M \& Golden SH. Atherosclerosis risk in communities study. Endogenous postmenopausal hormones and serum lipids: the atherosclerosis risk in communities study. Journal of Clinical Endocrinology and Metabolism 200590 1202-1209.

11 Deroo BJ \& Korach KS. Estrogen receptors and human disease. Journal of Clinical Investigation 2006116 561-570.

12 Koehler KF, Helguero LA, Haldosen LA, Warner M \& Gustafsson JA. Reflections on the discovery and significance of estrogen receptor beta. Endocrine Reviews 200526 465-478.

13 Venkov CD, Rankin AB \& Vaughan DE. Identification of authentic estrogen receptor in cultured endothelial cells. A potential mechanism for steroid hormone regulation of endothelial function. Circulation 199694 727-733.

14 Losordo DW, Kearney M, Kim EA, Jekanowski J \& Isner JM. Variable expression of the estrogen receptor in normal and atherosclerotic coronary arteries of premenopausal women. Circulation 199489 1501-1510.

15 Nakamura Y, Suzuki T, Miki Y, Tazawa C, Senzaki K, Moriya T, Saito H, Ishibashi T, Takahashi S, Yamada S \& Sasano H. Estrogen receptors in atherosclerotic human aorta: inhibition of human vascular smooth muscle cell proliferation by estrogens. Molecular and Cellular Endocrinology 2004219 17-26.

16 Karas RH, Patterson BL \& Mendelsohn ME. Human vascular smooth muscle cells contain functional estrogen receptor. Circulation 199489 1943-1950.

17 Liu PY, Christian RC, Ruan M, Miller VM \& Fitzpatrick LA. Correlating androgen and estrogen steroid receptor expression with coronary calcification and atherosclerosis in men without known coronary artery disease. Journal of Clinical Endocrinology and Metabolism 200590 1041-1046.

18 Sudhir K, Chou TM, Chatterjee K, Smith EP, Williams TC, Kane JP, Malloy MJ, Korach KS \& Rubanyi GM. Premature coronary artery disease associated with a disruptive mutation in the estrogen receptor gene in a man. Circulation 199796 3774-3777.

19 Shearman AM, Cupples LA, Demissie S, Peter I, Schmid CH, Karas RH, Mendelsohn ME, Housman DE \& Levy D. Association between estrogen receptor alpha gene variation and cardiovascular disease. JAMA $20032902263-2270$.

20 Schuit SC, Oei HH, Witteman JC, Geurts van Kessel CH, van Meurs JB, Nijhuis RL, van Leeuwen JP, de Jong FH, Zillikens MC, Hofman A, Pols HA \& Uitterlinden AG. Estrogen receptor alpha gene polymorphisms and risk of myocardial infarction. JAMA $20042912969-2977$.

21 Koch W, Hoppmann P, Pfeufer A, Mueller JC, Schomig A \& Kastrati A. No replication of association between estrogen receptor alpha gene polymorphisms and susceptibility to myocardial infarction in a large sample of patients of European descent. Circulation 2005112 2138-2242.

22 Rokach A, Pollak A, Rosen L, Friedlander Y, Blumenfeld A, Reznik L \& Dresner-Pollak R. Estrogen receptor alpha gene polymorphisms are associated with the angiographic extent of coronary artery disease. Journal of Clinical Endocrinology and Metabolism 200590 6556-6560. 
23 Lu H, Higashikata T, Inazu A, Nohara A, Yu W, Shimizu M \& Mabuchi H. Association of estrogen receptor-alpha gene polymorphisms with coronary artery disease in patients with familial hypercholesterolemia. Arteriosclerosis, Thrombosis, and Vascular Biology 200222 817-823.

24 Ferrero V, Ribichini F, Matullo G, Guarrera S, Carturan S, Vado A, Vassanelli C, Piazza A, Uslenghi E \& Wijns W. Estrogen receptoralpha polymorphisms and angiographic outcome after coronary artery stenting. Arteriosclerosis, Thrombosis, and Vascular Biology $2003232223-2228$.

25 Shearman AM, Cooper JA, Kotwinski PJ, Miller GJ, Humphries SE, Ardlie KG, Jordan B, Irenze K, Lunetta KL, Schuit SC, Uitterlinden AG, Pols HA, Demissie S, Cupples LA, Mendelsohn ME, Levy D \& Housman DE. Estrogen receptor alpha gene variation is associated with risk of myocardial infarction in more than seven thousand men from five cohorts. Circulation Research 200698 590-592.

26 Shearman AM, Cooper JA, Kotwinski PJ, Humphries SE, Mendelsohn ME, Housman DE \& Miller GJ. Estrogen receptor alpha gene variation and the risk of stroke. Stroke $2005 \mathbf{3 6}$ 2281-2282.

27 Pollak A, Rokach A, Blumenfeld A, Rosen LJ, Resnik L \& Dresner Pollak R. Association of oestrogen receptor alpha gene polymorphism with the angiographic extent of coronary artery disease. European Heart Journal 200425 240-245.

28 Petrovic D \& Peterlin B. Estrogen receptor dinucleotide (TA) polymorphism does not predict premature myocardial infarction in Caucasian women. Cardiology 200399 163-165.

29 Evangelopoulos D, Alevizaki M, Lekakis J, Cimponeriu A, Papamichael C, Kominakis A, Kalofoutis A \& Moutsatsou P. Molecular analysis of the estrogen receptor alpha gene in men with coronary artery disease: association with disease status. Clinica Chimica Acta $200333137-44$.

30 Yaich L, Dupont WD, Cavener DR \& Parl FF. Analysis of the PvuII restriction fragment-length polymorphism and exon structure of the estrogen receptor gene in breast cancer and peripheral blood. Cancer Research $1992 \mathbf{5 2}$ 77-83.

31 Saltiki K, Doukas C, Kanakakis J, Anastasiou E, Mantzou E \& Alevizaki M. Severity of cardiovascular disease in women: relation with exposure to endogenous estrogen. Maturitas $2006 \mathbf{5 5}$ 51-57.

32 Lehtimaki T, Laaksonen R, Mattila KM, Janatuinen T, Vesalainen R, Nuutila P, Laakso J, Jaakkola O, Koivula T \& Knuuti J. Oestrogen receptor gene variation is a determinant of coronary reactivity in healthy young men. European Journal of Clinical Investigation 200232 400-404.

33 Lehtimaki T, Kunnas TA, Mattila KM, Perola M, Penttila A, Koivula T \& Karhunen PJ. Coronary artery wall atherosclerosis in relation to the estrogen receptor 1 gene polymorphism: an autopsy study. Journal of Molecular Medicine 200280 176-180.

34 Mansur Ade P, Nogueira CC, Strunz CM, Aldrighi JM \& Ramires JA. Genetic polymorphisms of estrogen receptors in patients with premature coronary artery disease. Archives of Medical Research 200536 511-517.

35 Matsubara Y, Murata M, Kawano K, Zama T, Aoki N, Yoshino H, Watanabe G, Ishikawa K \& Ikeda Y. Genotype distribution of estrogen receptor polymorphisms in men and postmenopausal women from healthy and coronary populations and its relation to serum lipid levels. Arteriosclerosis, Thrombosis, and Vascular Biology 199717 3006-3012.

36 Parl FF, Cavener DR \& Dupont WD. Genomic DNA analysis of the estrogen receptor gene in breast cancer. Breast Cancer Research and Treatment 198914 57-64.

37 Hill SM, Fuqua SA, Chamness GC, Greene GL \& McGuire WL. Estrogen receptor expression in human breast cancer associated with an estrogen receptor gene restriction fragment length polymorphism. Cancer Research 198949 145-148.

38 Andersen TI, Heimdal KR, Skrede M, Tveit K, Berg K \& Borresen AL. Oestrogen receptor (ESR) polymorphisms and breast cancer susceptibility. Human Genetics 199494 665-670.
39 Cai Q, Shu XO, Jin F, Dai Q, Wen W, Cheng JR, Gao YT \& Zheng W. Genetic polymorphisms in the estrogen receptor alpha gene and risk of breast cancer: results from the Shanghai Breast Cancer Study. Cancer Epidemiology, Biomarkers and Prevention 200312 853-859.

40 Weiderpass E, Persson I, Melhus H, Wedren S, Kindmark A \& Baron JA. Estrogen receptor alpha gene polymorphisms and endometrial cancer risk. Carcinogenesis $200021623-627$.

41 Ioannidis JP, Ralston SH, Bennett ST, Brandi ML, Grinberg D, Karassa FB, Langdahl B, van Meurs JB, Mosekilde L, Scollen S, Albagha OM, Bustamante M, Carey AH, Dunning AM, Enjuanes A, van Leeuwen JP, Mavilia C, Masi L, McGuigan FE, Nogues X, Pols HA, Reid DM, Schuit SC, Sherlock RE \& Uitterlinden AG. GENOMOS study. Differential genetic effects of ESR 1 gene polymorphisms on osteoporosis outcomes. JAMA 2004 292 2105-2114.

42 Kobayashi S, Inoue S, Hosoi T, Ouchi Y, Shiraki M \& Orimo H. Association of bone mineral density with polymorphism of the estrogen receptor gene. Journal of Bone and Mineral Research 1996 11 306-311.

43 Deng HW, Li J, Li JL, Dowd R, Davies KM, Johnson M, Gong G, Deng H \& Recker RR. Association of estrogen receptor-alpha genotypes with body mass index in normal healthy postmenopausal Caucasian women. Journal of Clinical Endocrinology and Metabolism $2000 \mathbf{8 5} 2748-2751$.

44 Stavrou I, Zois C, Ioannidis JP \& Tsatsoulis A. Association of polymorphisms of the oestrogen receptor alpha gene with the age of menarche. Human Reproduction 200217 1101-1105.

45 Weel AE, Uitterlinden AG, Westendorp IC, Burger H, Schuit SC, Hofman A, Helmerhorst TJ, van Leeuwen JP \& Pols HA. Estrogen receptor polymorphism predicts the onset of natural and surgical menopause. Journal of Clinical Endocrinology and Metabolism 1999 84 3146-3150.

46 Luisi S, Galleri L, Marini F, Ambrosini G, Brandi ML \& Petraglia F. Estrogen receptor gene polymorphisms are associated with recurrence of endometriosis. Fertility and Sterility $2006 \mathbf{8 5}$ 746-764.

47 Peter I, Shearman AM, Zucker DR, Schmid CH, Demissie S, Cupples LA, Larson MG, Vasan RS, D’Agostino RB, Karas RH, Mendelsohn ME, Housman DE \& Levy D. Variation in estrogenrelated genes and cross-sectional and longitudinal blood pressure in the Framingham heart study. Journal of Hypertension 200523 2193-2200.

48 Kikuchi T, Hashimoto N, Kawasaki T \& Uchiyama M. Association of serum low-density lipoprotein metabolism with oestrogen receptor gene polymorphisms in healthy children. Acta Paediatrica $2000 \mathbf{8 9} 42-45$.

49 Shearman AM, Demissie S, Cupples LA, Peter I, Schmid CH, Ordovas JM, Mendelsohn ME \& Housman DE. Tobacco smoking, estrogen receptor alpha gene variation and small low density lipoprotein level. Human Molecular Genetics 200514 2405-2413.

50 Lo JC, Zhao X, Scuteri A, Brockwell S \& Sowers MR. The association of genetic polymorphisms in sex hormone biosynthesis and action with insulin sensitivity and diabetes mellitus in women at midlife. American Journal of Medicine 2006119 S69-S78.

51 Georgiou I, Konstantelli M, Syrrou M, Messinis IE \& Lolis DE. Oestrogen receptor gene polymorphisms and ovarian stimulation for in vitro fertilization. Human Reproduction 199712 1430-1433.

52 Gotoda T, Kinoshita M, Ishibashi S, Inaba T, Harada K, Shimada M, Osuga J, Teramoto T, Yazaki Y \& Yamada N. Skipping of exon 14 and possible instability of both the mRNA and the resultant truncated protein underlie a common cholesteryl ester transfer protein deficiency in Japan. Arteriosclerosis, Thrombosis, and Vascular Biology 199717 1376-1381.

53 O'Neill JP, Rogan PK, Cariello N \& Nicklas JA. Mutations that alter RNA splicing of the human HPRT gene: a review of the spectrum. Mutation Research $1998 \mathbf{4 1 1} 179-214$.

54 Herrington DM, Howard TD, Hawkins GA, Reboussin DM, Xu J, Zheng SL, Brosnihan KB, Meyers DA \& Bleecker ER. Estrogenreceptor polymorphisms and effects of estrogen replacement on high-density lipoprotein cholesterol in women with coronary disease. New England Journal of Medicine 2002346 967-974. 
55 Herrington DM, Howard TD, Brosnihan KB, McDonnell DP, Li X, Hawkins GA, Reboussin DM, Xu J, Zheng SL, Meyers DA \& Bleecker ER. Common estrogen receptor polymorphism augments effects of hormone replacement therapy on E-selectin but not C-reactive protein. Circulation 2002105 1879-1882.

56 Becherini L, Gennari L, Masi L, Mansani R, Massart F, Morelli A, Falchetti A, Gonnelli S, Fiorelli G, Tanini A \& Brandi ML. Evidence of a linkage disequilibrium between polymorphisms in the human estrogen receptor alpha gene and their relationship to bone mass variation in postmenopausal Italian women. Human Molecular Genetics 20009 2043-2050.
57 Alevizaki M, Cimponeriu A, Garofallaki M, Sarika H-L, Alevizaki CC, Papamichael C, Philippou G, Anastasiou E, Lekakis J \& Mavrikakis M. The androgen receptor CAG polymorphism is associated with the severity of coronary artery disease in men. Clinical Endocrinology 200359 749-755.

Received 17 November 2006

Accepted 5 February 2007 